Удк 663.969

\title{
ЛИСТЬЯ КАВКАЗСКОЙ ЕЖЕВИКИ (RUBUS CAUCASICUS L.)- ПЕРСПЕКТИВНОЕ СЫРЬЕ ДЛЯ ПРОИЗВОДСТВА ТРАВЯНОГО ЧАЯ
}

\author{
() Р.Г. Мелкадзе \\ Институт механики машин, ул. Миндели, 10 Тбилиси, 0186 (Грузия) \\ e-mail: revmelk@rambler.ru
}

\begin{abstract}
Исследованы некоторые физико-химические характеристики 6-листового побега ежевики кавказской (Rubus caucasicus L.). Установлено, что минимумы содержания влажности, экстрактных веществ и фенольных соединений совпадают с периодам начала и конца вегетации растения. Состав фенольных соединений представлен катехинами, лейкоантоцианидинами и флавонолами. Максимумы накопления фенольных соединений за вегетационный период отмечаются в середине сезона (июль-август). Сумма свободных аминокислот ежевичного листа по месяцам вегетации составляет в среднем 26,68 мг/г. Из идентифицированных 11 отдельных аминокислот 5 являются незаменимыми (Гис, Арг, Мет, Лей, Вал). В комплексе окислительных ферментов ежевичного листа установлено наличие активной формы О-дифенолоксидазы. Чайный продукт, полученный из ежевичного листа, характеризуется хорошими органолептическими показателями и насыщенным экстрактивным комплексом.

Ключевые слова: травяные чаи, ежевика кавказская, физико-химический состав, фенольные вещества, аминокислоты, окислительные ферменты, ежевичный чай, технологическая схема.
\end{abstract}

\section{Введение}

В последнее время травяной чай становится все более популярным, его производят многие известные чайные компании. По своей природе эти напитки не являются чаем, так как изготавливаются не из листьев кустарника чая, а из различных цветков, листьев и корневищ растений.

К ценностям травяного чая можно отнести и то, что он не содержит кофеина - вещества вредного для людей, страдающих нарушениями нервной и сердечно-сосудистой систем, и для детей до двух лет. Травяной чай можно давать детям любого возраста.

В Западной Европе, очень серьезно относящейся к здоровью ее жителей, травяные смеси пользуются огромной популярностью и используются не только в чистом виде, но и в качестве добавок к классическим черным и зеленым чаям.

Травяные чаи - это настоящий кладезь полезных натуральных микроэлементов и веществ, которые дарит нам сама природа. Входящие в состав травы и соцветия не только обогащают напиток витаминами, но и делают его изысканнее. Травяные чаи широко применяются для профилактики и лечения различных недугов, обладают укрепляющими и иммуностимулирующими свойствами, способствуют похудению, выведению шлаков из организма, успокаивают, бодрят, поддерживают организм в тонусе и просто дарят хорошее настроение.

На основе анализа данных о растениях, применяемых для приготовления травяных чаев, с учетом имеющихся ресурсов и народного опыта их применения, нами в качестве объекта исследования выбраны листья ежевики кавказской.

Ежевика относится к подроду Eubatus, рода Rubus L. семейства розоцветных, полукустарник высотой 50-150 см с многолетним корневищем и двулетними надземными стеблями, покрытыми шипами. На Кавказе встречается 33 вида ежевики. Из этих видов в Грузии главным образом распространена ежевика

Мелкадзе Реваз Георгиевич - ведущий научный сотрудник отдела спецпищевых продуктов и биопрепаратов, доктор технических наук, профессор, e-mail: revmelk@rambler.ru кавказская (Rubus caucasicum L.).

Растение цветет с мая по август, плодоносит приблизительно после 1,5 месяцев цветения. Растет в лесах, оврагах, среди кустарников, на вырубках, 
по берегам рек, ручьев, на лугах, каменистых склонах, в садах, огородах, вдоль дорог. Образует большие заросли. Общая площадь, занимаемая ежевикой в Грузии, составляет до 300 тыс. га.

Отличительной чертой ежевики кавказской от других видов ежевик является малое образование колючек на стеблях и листьях, что облегчает сбор сырья.

Существенно то, что периоды вегетации ежевики полностью совпадают с периодами сезона производства чая (апрель-октябрь). Это имеет большое значение в деле его производства на предприятиях первичной переработки чая.

Следует отметить, что сведения о химическом составе растения крайне скудны, за исключением работ, касающихся изучения механического состава 6-листового побега ежевики и отдельных фенольных соединений элементов флеша $[1,2]$, нет данных и о технологии переработки сырья и качественном составе готового продукта.

Изучение этих вопросов определило цель данного исследования.

\section{Объекты и методы исследования}

Объектами исследования служили листья ежевики кавказской, технологическое оборудование производства черного и зеленого чая, продукты ежевичного травяного чая и технологические схемы изготовления продукции.

В сырье за вегетационный период исследовались: влажность - высушиванием навески до постоянного веса, экстрактивные вещества - по методу В.Е. Воронцова [3], фенольные соединения - по Левенталю с применением пересчетного коэффициента $\mathrm{K}=4,16$, свободные аминокислоты - методом В.Р. Попова хроматографированием на бумаге [4], флавоноиды - фракционированием суммарных препаратов методом двумерной хроматографией [5-8], белковые вещества - микрометодом Кьелдаля, витамин С - титрованием раствора 2,6-дихлорфенолиндифенола, зольные элементы - методом мокрого сжигания по Ермакову, отдельные микроэлементы - с применением пламенного фотометра [9].

Качество полуфабрикатов и готовых продуктов устанавливалось с применением методов химического и дегустационного анализа.

\section{Экспериментальная часть}

Динамика влажности ежевичного листа за период вегетации. Исследования проводились на сезонном разрезе вегетации ежевичного листа. Для работы использовали 6-листовые побеги ежевики, в которых определяли влажность в 10-кратной повторностью (рис. 1).

Низкое содержание влажности ежевичного побега совпадает с периодом начала и конца вегетации (май и сентябрь), а самое высокое - периодом цветения и плодоношения (июнь-август).

Экстрактивные вещества, фенольный и аминокислотный составы. Из многочисленных веществ растительного сырья для приготовления чайного продукта наиболее важными, наряду с водой, являются фенольные соединения, эфирные масла, белки, углеводы, пигменты, ферменты, зольные вещества и др. Отдельные группы этих веществ имеют положительное, отрицательное или индифферентное значение для качества готового продукта.

Сухие вещества любого растительного сырья делятся на две группы - растворимые и нерастворимые в воде вещества. Обе группы по своим количественным соотношениям и качественными свойствами оказывают большое влияние на технологические процессы производства.

Одним из объективных и важнейших показателей качества чайного продукта является содержание экстрактивных веществ, которые при настаивании чая переходят в горячую воду.

Ввиду того, что в литературе отсутствуют данные об экстрактивных веществах ежевичного листа, в нашей работе мы проводили изучение его за вегетационный период (май-сентябрь). Данные исследования представлены на рисунке 2.

Из рисунка 2 следует, что самое низкое содержание экстрактивных веществ в ежевичном листе совпадает к периодам начала и конца вегетации (май и сентябрь), а максимум накопления их отмечается в августе. 


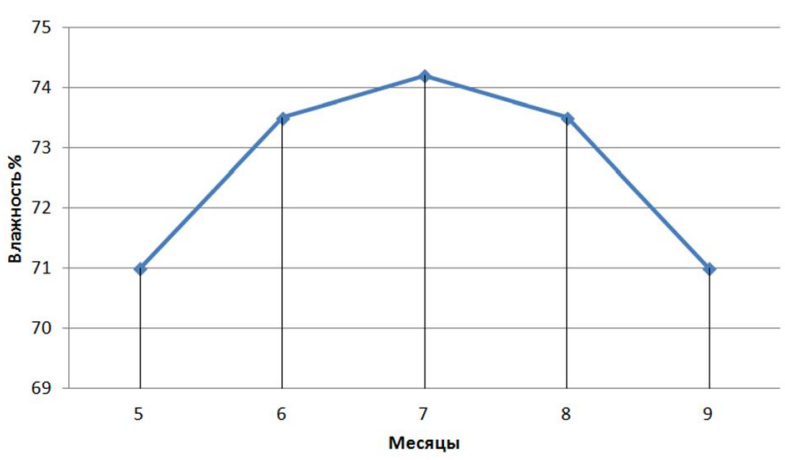

Рис. 1. Динамика влажности 6-листового побега ежевики по месяцам вегетации

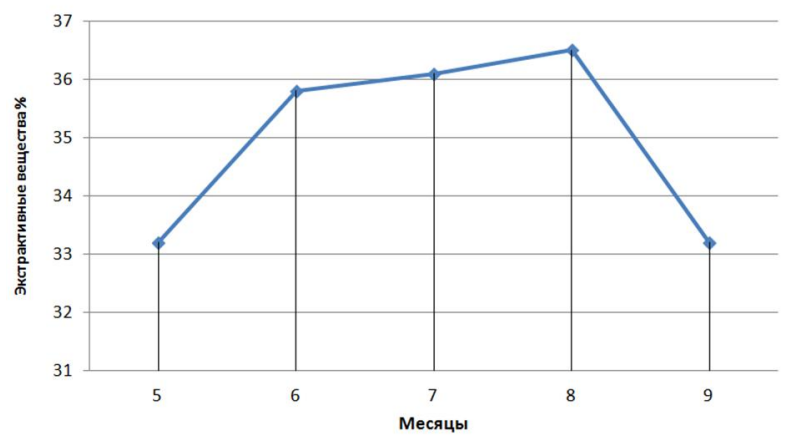

Рис. 2. Динамика содержания экстрактивных веществ в 6-листовом ежевичном побеге за вегетационный период

Среди веществ традиционного чая главное место занимает комплекс фенольных соединений.

В производстве чая фенольные соединения играют первостепенную роль, так как от их способности окисляться под действием ферментов с образованием красных и коричневых продуктов реакции зависят качественные характеристики готового продукта. Фенольные соединения чайного листа при изготовлении чая подвергаются глубоким и разнообразным превращениям, составляющим основу технологического процесса чайного производства. Поэтому понятна огромная работа, проведенная исследователями в области изучения роли фенольных соединений чая [10-15, 16, 17, 18-28].

В связи с изложенным выше при производстве травяного чая первостепенное значение имеет изучение фенольных соединений того или иного растительного сырья.

Особенно интересным представляется установление сезонной динамики фенольных соединений за вегетационный период растения. Как известно, содержание фенольных соединений в чайном листе подвержено изменениям в течение сезона переработки - для грузинского чайного растения максимум их накоплений при других одинаковых условиях наступает к середине сезона (июль-август), когда суточная суммарная атмосферная температура наивысшая. Подробные эксперименты нами проведены в ежевичном побеге за период вегетации (табл. 1).

В результате было установлено, что характер накопления фенольных веществ ежевичного побега по месяцам вегетационного сезона идентичен чайному листу. В ежевике, как и в чайном листе, максимум накопления фенольных веществ приходится на середину вегетационного периода - в самые жаркие периоды (июль-август). Это еще раз подтверждает, что лист ежевики, как чайный или другого растительного сырья, полностью подчиняется основным закономерностям онтогенеза растений.

В дальнейшей работе важным вопросом являлось изучение качественного состава фенольных соединений ежевичного листа.

В проведенной нами ранее работе [29] был установлен качественный состав фенольных веществ ежевичного листа, состоящий из трех групп флавоноидов: лейкоантоцианидинов, катехинов и флавонолов, двумерные хроматограммы которых представлены на рисунке 3.

При изучении динамики накопления флавоноидных веществ в ежевичном побеге за вегетационный период нами обнаружено, что после фазы цветения (май) количество катехинов, лейкоантоцианидинов и флавонолов возрастает в течение лета, достигая максимума в августе, а затем уменьшается (рис. 4-6).

Таблица 1. Динамика фенольных соединений ежевичного побега за вегетационный период

\begin{tabular}{c|c|c|c}
\hline № & Месяцы & $\begin{array}{c}\text { Фенольные соединения, } \\
\text { \% к сухой массе }\end{array}$ & $\begin{array}{c}\text { Степень от максимума накопления } \\
\text { фенольных соединений, \% }\end{array}$ \\
\hline 1 & Май & $16,70 \pm 0,24$ & 82,1 \\
2 & Июнь & $18,84 \pm 0,22$ & 82,5 \\
3 & Июль & $19,61 \pm 0,33$ & 96,4 \\
4 & Август & $20,35 \pm 0,37$ & 100,0 \\
5 & Сентябрь & $16,65 \pm 0,21$ & 81,8 \\
\hline & Среднее за 4 года наблюдений & $18,43 \pm 0,30$ & \\
\hline
\end{tabular}




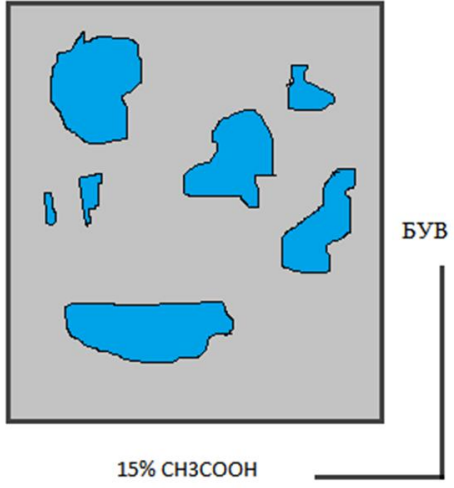

Фракция 1

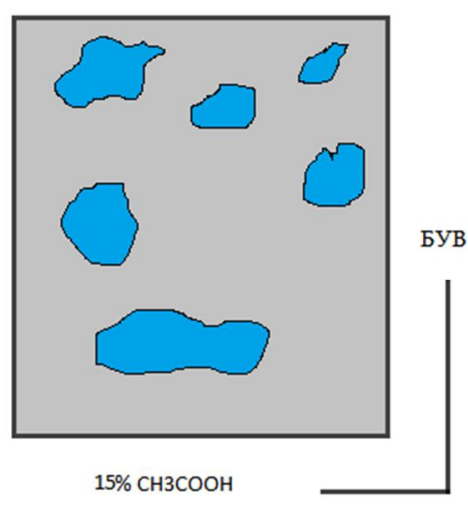

Фракция 2

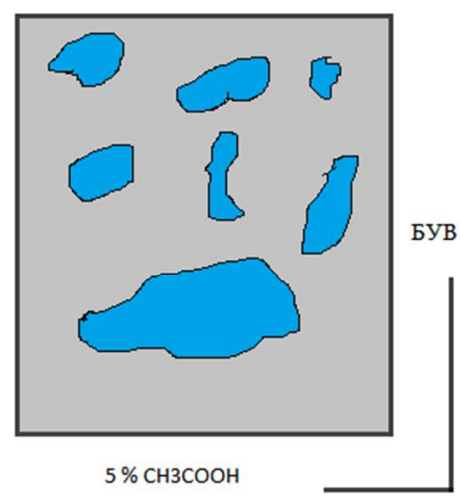

Фракция 3

Рис. 3. Двумерная хроматограмма фракции суммарного препарата флавоноидов ежевичного листа; 1 - направление - БУВ (н-бутанол - уксусная кислота - вода $4: 1: 5$; верхняя фаза); 2 - направление $15 \%$ уксусная кислота (нижняя фаза)

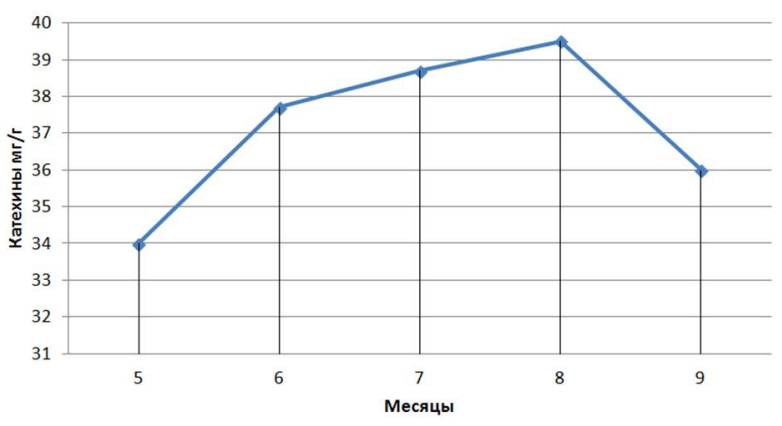

Рис. 4. Динамика катехинов в ежевичном побеге при вегетации

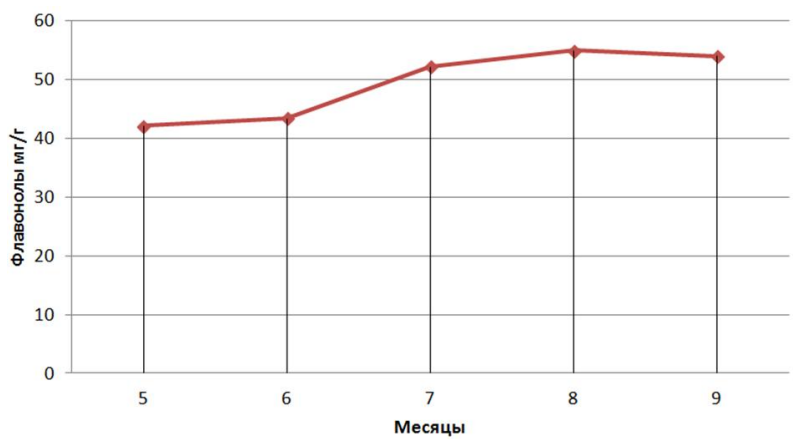

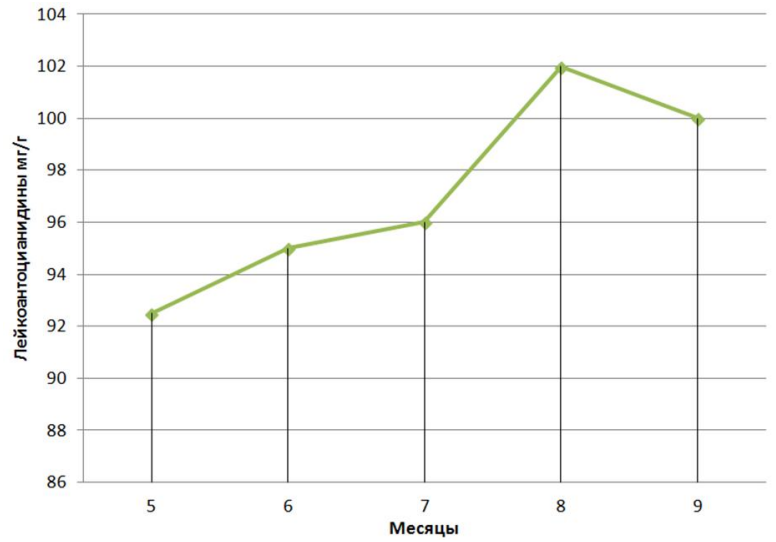

Рис. 5. Динамика лейкоантоцианидинов в ежевичном побеге при вегетации

Рис. 6. Динамика флавонолов в ежевичном побеге при вегетации

Характер динамики флавоноидов в ежевичном побеге и их количественные изменения в период вегетации указывают на то, что эти вещества принимают активное участие в обменных процессах растительной клетки [5, 22, 30-32].

Как известно, из многочисленных химических веществ чайного листа при производстве чая большую роль играют белковые вещества и аминокислоты. В основе строения белков лежит сложное сочетание различных аминокислот.

Значение белковых веществ в формировании качества чая заключается, помимо участия их в ферментативных реакциях, в том, что они являются источниками аминокислот: при переработке листа проис- 
ходит частичный их гидролиз, а образующиеся при этом аминокислоты, согласно имеющимся данным [15], принимают непосредственное участие в образовании аромата чая.

Исследованиями, проведенными советскими и зарубежными учеными при изучении аминокислотного состава чайного листа, в нем обнаружены 17 отдельных аминокислот [33, 34].

С учетом важности белковых веществ и аминокислот при производстве чая мы провели работы по изучению их наличия в составе ежевичного листа. Количественное определение белков проводили по содержанию общего азота с применением микрометода Кьелдаля [9, 35]. Одновременно проводили также количественное определение общей суммы свободных аминокислот в сезонной вегетации 6-листового ежевичного побега (табл. 2).

Как видно, содержание белков в начале вегетации максимальное, далее оно постепенно уменьшается, а минимум приходится на июль-август. В этих же месяцах отмечается максимум накопления свободных аминокислот.

Особенно интересным представлялось изучение отдельных аминокислот в белках ежевичного листа. С применением метода хроматографии на бумаге нами были выделены 11 индивидуальных аминокислот и установлено их количественное содержание (табл. 3). Как видно, ежевичный лист характеризуется высоким качественным составом отдельных аминокислот: из 11 идентифицированных нами аминокислот 5 являются незаменимыми (гистидин, аргинин, метионин, лейцин, валин). Сопоставление их количественного содержания с чайным листом [36] показывает, что суммарное содержание лизин + гистидин в ежевичном листе 7,8 раз больше, чем в чайном (4,3 мг/г против 0,55 мг/г), лейцина - 9,1 раза больше (2,55 мг/г против $0,28 \mathrm{M \Gamma} / \Gamma)$.

Валин в обоих растениях содержится приблизительно одинаковых количествах $(0,85$ мг/г в ежевичном листе и 0,68 мг/г - в чайном). Одновременно в ежевичном листе содержится 2,21 мг/г метионина, который в чайном листе не обнаружен.

По общей сумме аминокислот ежевичный лист значительно превосходит чайный (26,7 мг/г против 17,45 мг/г), а по суммарному содержанию незаменимых аминокислот это превосходство выражается в 9,61 мг/г (11,67 мг/г в ежевичном листе и 2,06 мг/Г - в чайном). Если учесть, что из незаменимых аминокислот гистидин является необходим для нормального роста младенцев [32], и принять во внимание отсутствие в ежевичном листе сильнодействующих алкалоидов, в том числе кофеина, то создается хорошая основа широкого использования ежевичного чая в качестве диетического и детского питания.

Таблица 2. Содержание белковых веществ и свободных аминокислот в ежевичном побеге при вегетации

\begin{tabular}{c|c|c|c|c}
\hline \multirow{2}{*}{$№$} & \multirow{2}{*}{ Месяцы } & \multicolumn{2}{|c|}{ Белковые вещества, \% на сухую массу } & Сумма свободных ами- \\
\cline { 2 - 3 } & Мой & общий азот & белки & 26,15 \\
1 & Май & 0,381 & 2,381 & 26,56 \\
2 & Июнь & 0,364 & 2,275 & 27,47 \\
3 & Июль & 0,360 & 2,250 & 27,82 \\
4 & Август & 0,360 & 2,250 & 25,40 \\
5 & Сентябрь & 0,372 & 2,325 & 26,68 \\
\hline \multicolumn{2}{c|}{ Среднее за период вегетации } & 0,367 & 2,296 & \\
\hline
\end{tabular}

Окислительные ферментыл. Ферменты, главным образом окислительные, лежат в основе проведения биохимических процессов чайного производства, вызывая важнейшие биохимические превращения, способствующие образованию специфических вкусовых и ароматических веществ готового продукта. Исследованию ферментов в чайном листе и готовом чае посвящены многочисленные работы [3, 10, 25, 34, 36-48]. В результате этих работ установлено, что в чайном листе присутствуют весьма активные окислительные ферменты - О-дифенольоксидаза и пероксидаза. Выяснилось также, что основные окис-
Таблица 3. Содержание отдельных аминокислот в ежевичном побеге

\begin{tabular}{c|l|c}
\hline № & \multicolumn{1}{|c}{ Аминокислоты } & $\begin{array}{c}\text { Содержание аминокислот, } \\
\text { мг/г сухого вещества }\end{array}$ \\
\hline 1 & Цистеин & 0,92 \\
2 & Лизин & 1,67 \\
3 & Гистидин & 2,63 \\
4 & Аспарагин & 2,66 \\
5 & Аргинин & 3,43 \\
6 & Глютаминовая кислота & 3,01 \\
7 & Тирозин & 4,02 \\
8 & Метионин & 2,21 \\
9 & Лейцин & 2,55 \\
10 & Фенилаланин & 2,53 \\
11 & Валин & 0,85 \\
\hline \multicolumn{2}{|c}{ Сумма } \\
\hline \multicolumn{2}{|c}{} \\
\hline
\end{tabular}


лительные процессы в чайном листе как в течение его роста и развития, так и во время переработки, осуществляются указанными ферментами $[10,15,40,48,49]$, при помощи которых происходит превращение соответствующих субстратов в живом чайном листе и в процессе его переработки.

Учитывая вышеизложенное, мы провели изучение окислительных ферментов ежевичного листа при изготовлении из него травяного чая. В основе экспериментов лежало получение ацетонового препарата ежевичного листа и исследование его активности по отношению к чайному танину и фенольным веществам ежевики.

Для получения ацетонового препарата 500 г свежих ежевичных побегов помещали в специальное измельчающее устройство, имеющее рубашку для жидкого азота и снабженное острым вращающимся ножом (7-8 тыс.об/мин). В данном устройстве материал быстро замораживали и в таком состоянии измельчали до полного разрушения тканей (3-5 мин). Затем измельченный лист обрабатывали в гомогенизаторе 2-3 раза по 1 мин охлажденным $\left(-15^{\circ} \mathrm{C}\right) 80 \%$ ацетоном. Каждый раз суспензию отфильтровали через воронку Бухнера, а осадок промывали небольшим количеством сухого ацетона. Осадок высушивали при комнатной температуре в токе воздуха.

Преимущество этого метода заключается в том, что, помимо быстрого удаления фенольных соединений, он дает также возможность переработать значительное количество сырья, необходимое для выделения и очистки высокомолекулярной фенолоксидазы [49].

Активность ацетонового препарата ежевичного листа к чайному танину определяли амперметрическим методом на полярографе. Реакционная среда: 10 г ацетонового препарата и 1 мл 0,1 М цитратнофосфатного буфера $\mathrm{pH} 5,7$. К этой реакционной смеси микропипеткой добавляли 20 мкл 0,35 М водного раствора чайного танина (312 мг в 2 мл воды) с молекулярным весом 450. Полярографическую ячейку предварительно термостатировали на $25^{\circ} \mathrm{C}$. Далее вычисляли активность в пересчете на 1 мг ацетонового препарата. Она составляла 20 нмоль $\mathrm{O}_{2} /$ мин 'мг.

Контрольная реакционная среда была та же, только полярографическую ячейку предварительно обрабатывали в термостате ацетоновым препаратом при $100{ }^{\circ} \mathrm{C}$ в течение 1 ч. Активность ацетонового препарата ежевичного листа к фенольным веществам ежевики определялась также амперметрическим методом на полярографе и была следующей: реакционная среда - 10 мг ацетонового препарата ежевичного листа, 1 мл 0,1 М цитратно-фосфатного буфера $\mathrm{pH}$ 5,7. К этой реакционной среде добавляли 20 мкл водного раствора ( 312 мг фенольного вещества, растворенного в 2 мл воды), температура среды $-25^{\circ} \mathrm{C}$.

После вычисления активность составляла 25 нмоль/мин ммг в пересчете на 1 мг ацетонового препарата. Контрольная реакционная среда была аналогична отмеченной выше.

Изучение активности ацетонового препарата к чайному танину проводили также в аппарате Варбурга. Реакционная среда: 25 мг ацетонового препарата ежевичного листа, 2,3 мл 0,1 М цитратно-фосфатного буфера рН 5,7, 126 мг чайного танина растворяли в 1,75 мл воды и получали 0,16 М танина, 0,5 мл которого вносили в реакционную среду. В центр аппарата Варбурга вносили 0,2 мл $5 \mathrm{M} \mathrm{NaOH}$.

Отчет проводили через каждые 15 мин. В посуде термобарометра имели ту же реакционную среду, только ацетоновый препарат предварительно обрабатывали в термостате при $100{ }^{\circ} \mathrm{C}$ в течение 1 ч для полной инактивации ферментов ацетонового препарата.

На рисунке 7 показаны данные об активности ацетонового препарата из листьев ежевики в отношении окисления чайного танина.

Из полученных результатов следует, что ацетоновый препарат ежевичного листа обладает способностью окислять суммарный препарат чайного танина. Указанное немного противоречит литературным данным о том, что дубильные вещества чая окисляются лишь собственными ферментами и проявляют четкое ингибирующее действие к ферментам других растений $[8,37,39]$. Однако в этих работах были использованы ферменты определенных растений (ячмень, миндаль, хрен). Видимо, в этом отношении листья ежевики являются исключением.

Для установления наличия в ферментном препарате ежевичного листа О-дифенолоксидазы проведены эксперименты в присутствии ингибитора диэтилдитиокарбамата. Для этого 15 мг натрия диэтилдитиокарбамата растворяли в 2 мл воды. Отсчет активности проводили на полярографе амперметрическим методом. Реакционная среда: 0,8 мл цитратно-фосфатного буфера $\mathrm{pH}$ 5,7, 0,2 мл водного раствора натрия в диэтилдитиокарбамате, 10 мг ацетонового препарата чайного танина. К этой реакционной среде добавляли 0,35 М водный раствор чайного танина (312 мг в 2 мл воды).

Во втором опыте к реакционной среде, приготовленной по отмеченной выше последовательности, добавляли 20 мкл водного раствора фенольных веществ ежевичного листа. 
Рис. 7. Активность ацетонового препарата листьев ежевики по окислению чайного танина

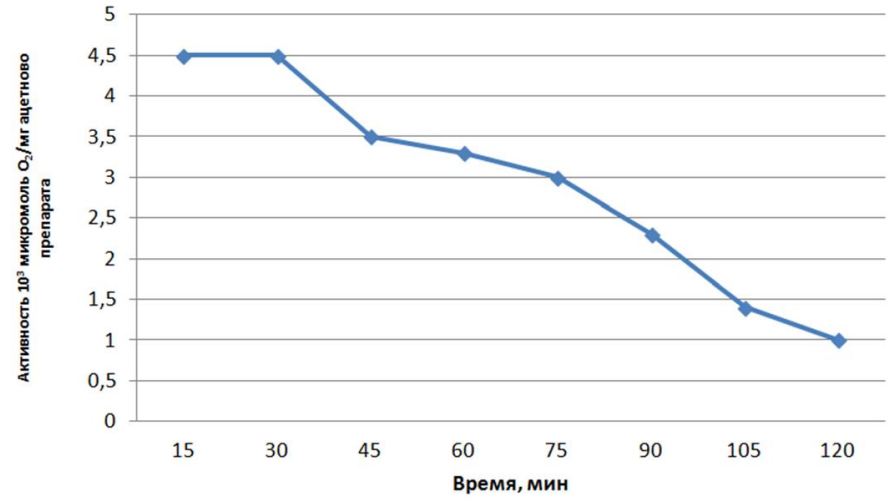

Как в первом, так и во втором случае не отмечалось поглощение кислорода, из чего следует, что окисление препаратов чайного танина и фенольных веществ ежевичного листа вызвано О-дифенолоксидазой. Полученные результаты свидетельствуют об активном участии ферментов ежевичного листа в биохимических окислительных процессах при производстве чайного продукта.

Технология ежевичного травяного чая. Эксперименты по переработке ежевичного листа проводились на модельных опытах. Для этого свежесобранные ежевичные листья завяливали в естественных условиях до 60-68\% остаточной влажности, скручивали в лабораторном роллере, снабженном прессом, в течение 60-120 мин, ферментировали при комнатной температуре $\left(20-24{ }^{\circ} \mathrm{C}\right)$ и относительной влажности 95$98 \%$ с различной продолжительностью и сушили на фен-аппарате при температуре $95-100{ }^{\circ} \mathrm{C}$ до остаточной влажности 6-7\% [29, 50-52].

В ходе экспериментов определяли степень разрушения клеток листа во время скручивания и глубину окисления фенольных веществ. Качество полученного полуфабриката оценивали дегустационным методом.

В зависимости от режимов технологической переработки из этой серии опытов были выделены 3 варианта, режимные параметры которых и характеристики выработанных продуктов представлены в таблице 4.

Как и следовало ожидать, количество разрушенных клеток скрученного листа непосредственно зависит от продолжительности скручивания, а с увеличением продолжительности процесса ферментации увеличивается и количество окисленных фенольных веществ листа. Из вариантов опытов наилучшими качественными показателями выделяются варианты I и II.

В полученных образцах изучали содержание экстрактивных и фенольных веществ (табл. 5).

Таблица 4. Влияние режимов переработки ежевичного листа на качественные показатели полуфабриката

\begin{tabular}{|c|c|c|c|c|}
\hline \multirow[t]{2}{*}{ № } & \multirow[t]{2}{*}{ Наименование } & \multicolumn{3}{|c|}{ Опыты } \\
\hline & & вариант I & вариант II & вариант III \\
\hline \multicolumn{5}{|c|}{ Технологические характеристики } \\
\hline 1 & $\begin{array}{l}\text { Остаточная влажность } \\
\text { завяленного листа, \% }\end{array}$ & $60-62$ & $63-65$ & $66-68$ \\
\hline 2 & $\begin{array}{l}\text { Продолжительность } \\
\text { скручивания, мин }\end{array}$ & $60-80$ & $80-100$ & $100-120$ \\
\hline 3 & $\begin{array}{l}\text { Количество разрушен- } \\
\text { ных клеток, \% }\end{array}$ & 67 & 74 & 78 \\
\hline 4 & $\begin{array}{l}\text { Продолжительность } \\
\text { ферментации, мин }\end{array}$ & $30-60$ & $60-90$ & $90-120$ \\
\hline 5 & $\begin{array}{l}\text { Глубина окисления } \\
\text { фенольных веществ, \% }\end{array}$ & 28,4 & 36,5 & 47,8 \\
\hline \multicolumn{5}{|c|}{ Качественные характеристики полуфабриката } \\
\hline 1 & Аромат & $\begin{array}{c}\text { Цветочно-фруктовый, } \\
\text { приятный, нежный, } \\
\text { специфический }\end{array}$ & $\begin{array}{c}\text { Цветочно-фруктовый, } \\
\text { приятный, нежный, } \\
\text { специфический }\end{array}$ & $\begin{array}{c}\text { Приятный, нежный, } \\
\text { специфический }\end{array}$ \\
\hline 2 & Вкус & $\begin{array}{c}\text { Терпкий, сильно вяжущий, } \\
\text { кисловатый }\end{array}$ & $\begin{array}{c}\text { Терпкий, сильно- } \\
\text { вяжущий, кисловатый }\end{array}$ & $\begin{array}{c}\text { Терпкий, вяжущий, } \\
\text { кисловатый }\end{array}$ \\
\hline 3 & Настой & $\begin{array}{c}\text { Выше среднего, яркий, } \\
\text { чистый, медно- } \\
\text { коричневый }\end{array}$ & $\begin{array}{c}\text { Выше среднего, яркий, } \\
\text { чистый, медно- } \\
\text { коричневый }\end{array}$ & $\begin{array}{c}\text { Выше среднего, } \\
\text { интенсивный, темно- } \\
\text { коричневый }\end{array}$ \\
\hline 4 & Внешний вид & $\begin{array}{c}\text { Пестрый, с бело-серыми } \\
\text { частицами }\end{array}$ & $\begin{array}{c}\text { Пестрый, с бело-серыми } \\
\text { частицами }\end{array}$ & $\begin{array}{c}\text { Пестрый, с бело-серыми } \\
\text { частицами }\end{array}$ \\
\hline
\end{tabular}


Таблица 5. Содержание экстрактивных и фенольных веществ в образцах полуфабриката ежевичного чая (\% к сухой массе)

\begin{tabular}{c|c|c|c}
\hline № & Вариант выработки полуфабриката & Экстрактивные вещества & Фенольные соединения \\
\hline 1 & I вариант & 27,09 & 11,25 \\
2 & II вариант & 26,84 & 10,37 \\
3 & III вариант & 26,66 & 9,34 \\
\hline
\end{tabular}

Из таблицы 5 следует, что в образцах полуфабриката ежевичного чая, выработанных по укороченной продолжительности ферментации, и следовательно, меньшей глубиной окисления фенольных соединений, насыщенность экстрактивным комплексом максимальна.

На основе полученных результатов можно сделать вывод о том, что в формировании органолептических и химических показателей ежевичного чая главная роль принадлежит процессу ферментации - ее продолжительности. Оптимальные пределы продолжительности процесса ферментации ежевичного листа (при прочих одинаковых условиях), при которых достигаются наилучшие вкусовые и ароматические показатели полуфабриката, лежат в довольно широком интервале - от 50 до 130 мин. В экспериментах было обнаружено, что ежевичные листья плохо поддаются скручиванию. Это обусловлено наличием на стеблях и листьях колючих шипов, способствующих образованию комков во время переворачивания массы в роллере из-за сил трения, что препятствует свободному передвижению листьев. Для устранения этого недостатка обязательным стало дополнительное применение в роллере пресса.

Ввиду того, что промышленность в настоящее время не производит роллеры, снабженные прессами, мы задались целью проведения процесса механического разрушения клеток с применением резальноизмельчающих машин, для чего была испытана бытовая мясорубка типа «Куттер».

Последовательность опытов была следующая: завяленные ежевичные листья пропускали в мясорубке «Куттер» одно- или многократно, измельченную массу в зависимости от степени окисления фенольных веществ ферментировали и сушили.

В результате проведенных опытов установлено, что при переработке ежевичного листа с применением резально-измельчающих машин достигается получение чая с наилучшими органолептическими показателями и высокой степенью насыщенности экстрактивным комплексом, существенным сокращением технологического цикла. При этом наиболее оптимальным является вариант, предусматривающий резку-измельчение сырья с кратковременной ферментацией резаного листа, хотя по степени разрушения клеток данный вариант уступает другим, однако указанное не влияет отрицательно на качество полученного продукта.

На основе проведенных работ можно заключить, что ежевичный лист является перспективным сырьем для получения травяного чая.

Ввиду особенности структурного строения листьев (побегов) ежевики при их переработке предпочтение отдается интенсивным физико-механическим методам воздействия (резка-измельчение), обеспечивающим при этом существенное сокращение технологического цикла.

Химический состав и технологическая схема производства ежевичного чая. Как известно, потребительская ценность готового чая наряду с органолептическими характеристиками во многом зависит от содержания в нем водорастворимых веществ, переходящих в настой при заварке, и от их количественного и качественного состава, определяющего биологическую и пищевую ценность продукта.

В нашей работе мы попытались изучить некоторые вещества экстрактивного комплекса ежевичного чая. Из многочисленных веществ, содержащихся в экстракте, мы исследовали количественное содержание экстрактивных и фенольных веществ, свободных аминокислот, зольных макроэлементов, витамина С и белковых веществ.

В качестве объекта исследования служил образец ферментированного ежевичного чая, изготовленный путем двухкратной резки-измельчения листа (табл. 6).

Полученные результаты показывают, что ежевичный чай характеризуется довольно богатым экстрактом, главным образом фенольными веществами и свободными аминокислотами. По этим показателям он не уступает натуральным видам байхового чая.

На основе проведенных исследований и модельных опытов разработана технологическая схема производства ежевичного чая [53] (рис. 8). 
Таблица 6. Химический состав ежевичного чая

\begin{tabular}{|c|c|c|c|c|c|c|c|c|c|}
\hline \multirow{2}{*}{ Образец } & \multirow{2}{*}{ ЭВ, \% } & \multirow{2}{*}{$\Phi С, \%$} & \multirow{2}{*}{$\begin{array}{l}\mathrm{AK}, \\
\mathrm{M \Gamma} / \Gamma\end{array}$} & \multirow{2}{*}{$3 \mathrm{~B}, \%$} & \multicolumn{3}{|c|}{ Макроэлементы. } & \multirow{2}{*}{ БВ, \% } & \multirow{2}{*}{$\begin{array}{c}\text { Витамин C, } \\
\text { мг } / \%\end{array}$} \\
\hline & & & & & $\mathrm{Na}$ & $\mathrm{Ca}$ & $\mathrm{K}$ & & \\
\hline $\begin{array}{c}\text { Ферментированный } \\
\text { ежевичный чай }\end{array}$ & 27,8 & 11,6 & 22,22 & 7,64 & 0,40 & 0,36 & 3,31 & 2,03 & 9,36 \\
\hline
\end{tabular}

Примечания. ЭВ - экстрактивные вещества; ФС - фенольные соединения; АК - аминокислоты; ЗВ - зольные вещества; БВ - белковые вещества.

Рис. 8. Технологическая схема производства ежевичного чая

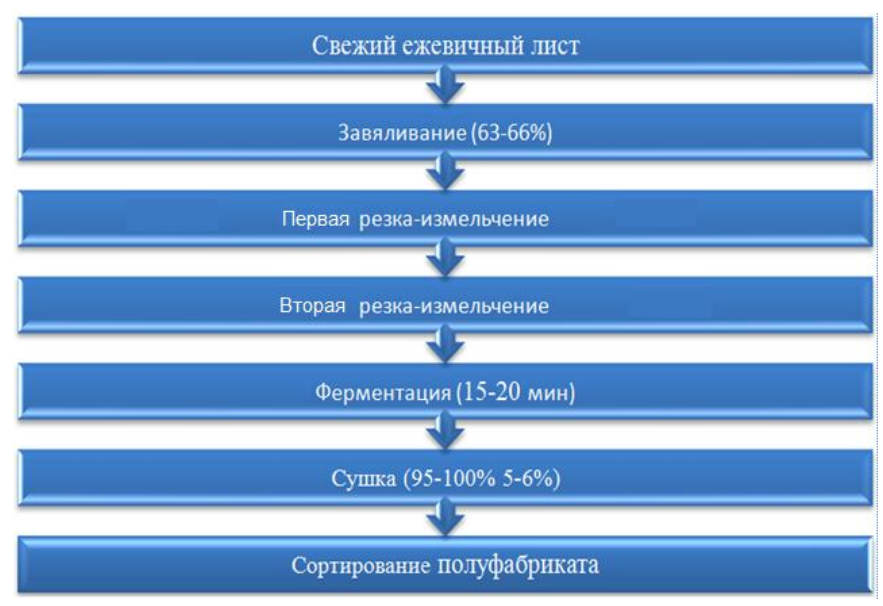

\section{Bыводbl}

Обоснована целесообразность ежевичного листа вида Rubus caucasicum L. в качестве сырья для производства травяных чаев и добавки к черному и зеленому чаю.

Исследована динамика влажности ежевичного листа за вегетационный период растения.

Изучен химический состав 6-листового ежевичного побега с увязкой вегетационного периода. Установлено, что характер накопления водорастворимых веществ и фенольных соединений изменчив: их минимальные содержания совпадают к периодами начала и конца вегетации (май и сентябрь).

Установлен характер изменения содержания отдельных фенольных веществ: катехинов, лейкоантоцианидинов и флаванолов ежевичного листа по месяцам вегетационного периода.

Изучено содержание в ежевичном листе отдельных аминокислот. Показано, что из 11 идентифицированных аминокислот 5 являются незаменимыми, это делает ежевичный лист перспективным сырьем для производства чайных продуктов детского и диетического питания.

Изучены окислительные ферменты ежевичного листа и установлено наличие активной формы О-дифенолоксидазы.

Показано, что биологическая и химическая особенности ежевичного листа играют положительную роль в интенсификации технологических процессов переработки сырья на ферментированный ежевичный травяной чай. Установлены качественные характеристики продукта и разработана технологическая схема производства.

\section{Список литературы}

1. Melkadze R., Chikovani N., Kachniashvili E. Characteristics of the Composition of Caucasian Blackberry (Rubus caucasicus L.) Leaves as a Raw Material for Tea Production // J. Applied Biochemistry and Microbiology. 2008. Vol. 44, N6. Pp. 647-651.

2. Melkadze R.G.Research an elemental composition Blackberry of a sheet and mining of the technological rules of effecting phytotea of products // Georgian Academy of Sciences. Tbilisi, 2000. N5. Pp. 39-50.

3. Воронцов В.Е. Биохимия чая. М., 1946. 291 с.

4. Попов В.Р.Количественное определение танина и свободных аминокислот при развитии побегов чая и во время их технологической переработки // Биохимия и прогрессивная технология чайного производства. М., 1966. С. $110-115$.

5. Дурмишидзе С.В. Дубильные вещества и антоцианы виноградной лозы и вина. М., 1955. 324 с.

6. Дурмишидзе С.В., Нуцубидзе Н. Хроматографическое разделение дубильных веществ винограда // Труды НИИ винограда и виноделия АН ГрузССР. 1954. Т. VIII. С. 360.

7. Соболева Г.А.Количественное определение катехинов при помощи денситометра // Биохимия чайного производства. М., 1958. Сб. 7. С. 76. 
8. Шипалов М.С., Бокучава М.А., Соболева Г.А. Применение денситометра для количественного определения катехинов, разделенных методом хроматографии на бумаге // Труды Института физиологии растений АН СССР. М., 1962. №4. С. 95.

9. Филиппович Ю.Б., Егоров Т.А., Севастьянова Г.А. Практикум по общей биохимии. М., 1975. 318 с.

10. Бокучава М.А. Дубильные вещества и окислительные ферменты грузинского чая : автореф. дис. ... д-ра хим. наук. М., 1950. 35 с.

11. Бокучава М.А. О природе и значении дубильных веществ чайного листа // Биохимия чайного производства. М., 1950. Сб. 6. С. 20-30.

12. Бокучава М.А.,Волкова А.Г. Превращение различных фракции дубильных веществ при росте и развитии чайного листа и при его переработке // Рефераты работ учреждений отделения биологических наук АН СССР за 1945 г. М., 1946.

13. Бокучава М.А., Новожилов Н.П. Вкусовые свойства отдельных фракции чайного танина и их значение для качества чая // Биохимия чайного производства. М., 1946. Сб. 5. С. 190.

14. Бокучава М.А., Попов В.Р. Значение аминокислот в образовании аромата чая при взаимодействии их с дубильными веществами в условиях повышенной температуры // Доклады АН СССР. 1954. №99. С. 145.

15. Бокучава М.А., Попов В.Р., Шуберт Т.А.Роль дубильных веществ в окислительно-восстановительных процессах растений // Доклады АН СССР. 1951. №76. С. 439.

16. Джемухадзе К.М. Чайный танин в связи с переработкой и качеством чая // Биохимия чайного производства. М., 1940. Сб. 4. С. 35-52.

17. Джемухадзе К.М. Дубильные вещества и качество чайного сырья // Биохимия чайного производства. М., 1950. Сб. 6. С. 39-52.

18. Курсанов А.Л. Образование и природа чайных пигментов // Биохимия чайного производства. М., 1935. Сб. 1. C. $110-127$.

19. Курсанов А.Л. Определение различных форм дубильных веществ в растениях // Биохимия. 1941. №6. С. 312.

20. Курсанов А.Л. Превращение дубильных веществ при переработке чайного листа // Биохимия. 1943. №8. С. 188.

21. Курсанов А.Л. Дубильные вещества чайного листа в связи с проблемой повышения качества чая // Известия АН СССР. Сер Биол. 1951. №2. С. 44.

22. Курсанов А.Л. Синтез и превращение дубильных веществ в чайном растении // 7-е Баховское чтение. АН СССР. М., 1952.

23. Курсанов А.Л., Крюкова Н.И. Синтез полифенолов в листьях чая // Биохимия чайного производства. М., 1950. Сб. 6. С. 7-19.

24. Bradfield A. Some recent developments in the chemistry of Tea // Chem. and Ind. 1946. Vol. 326. Pp. 242.

25. Lame J. Research and the practical manufacture of Tea // J. of res. Inst. of Ceylon. 1937. Pp. 36.

26. Roberts E., Wood D.A. A study of the polyphenols in tea leaf by paper chromatography // Biochem. J. 1951. N49. P. 414.

27. Tsujimura M. Ellagil acid in green tea // Chem.abstr. 1947. N41. P. 5924.

28. Tsujimura M., Takasu E. On the tea tannins in green tea Isolation of tea tannin in crystalline state // Ibid. 1955. P. 407.

29. Мелкадзе Р. Производство заменителя чая из листьев ежевики // Пиво и напитки. 2004. №2. С. 102-105.

30. Бохинский Р. Современные воззрения в биохимии: пер.с англ. М., 1987. 544 с.

31. Гудвин Т., Мерсер Э. Введение в биохимию растений: в 2 т. М., 1986. Т. 2. 312 с.

32. Кретович В.Л. Основы биохимии растений. М., 1971. 464 с.

33. Бокучава М.А., Попов В.Р., Сидоров В.С. Хроматографическое разделение свободных аминокислот свежего и завяленного чайного листа // Доклады АН СССР. 1954. №95. С. 609.

34. Oshima J., Nakabayashi T., Sakamoto J. Studies on the black tea tannin. Pt.1. Chemical changes of the poliphenol compounds and aminoacids in the manufacture of black tea // Ibid. 1954. P. 264.

35. Петров К.П. Практикум по биохимии растительного сырья. М., 1965. 330 с.

36. Глазунов И.В.Динамика ферментного действия (инвертаза чайного листа) // Биохимия чайного производства. М., 1935. Сб. 1. С. 76-87.

37. Курсанов А.Л. Условия работы ферментов в скрученном чайном листе // Биохимия чайного производства. М., 1935. Сб. 1. С. 88-94.

38. Манская С.М. Пероксидаза чайного листа // Биохимия чайного производства. М., 1935. Сб. 1. С. 96-109.

39. Опарин А.И. Биохимическая теория чайного производства // Биохимия чайного производства. М., 1935. Сб. 1. C. 6-19.

40. Опарин А.И., Шуберт Т.А. О дыхательных окислительных системах чайного листа // Биохимия чайного производства. М., 1935. Сб. 1.

41. Харебава Г.И. Ферментативные процессы в живом чайном листе // Биохимия чайного производства. М., 1946. Сб. 6. С. 85 .

42. Харебава Г.И. Пероксидаза чайного листа // Бюллютень ВНИИЧ и СК. 1949. №4. С. 49.

43. Harrison C., Roberts E. Fermentation process in tea manufacture // J. Biochem. 1939. N33. Pp. 1408-1420.

44. Roberts E. The fermentation process in tea manufacture // J. Biochem. 1939. N33. P. 842.

45. Roberts E. The nature of tea oxidase system // Ibid. 1941. N35. P. 10.

46. Roberts E. The chemistry of tea fermentation // Enzimol. 1942. N2. P. 113.

47. Roberts E. The fermentation process in tea manufacture: Cytochrome oxidase and its probable role. 6 . The effect of dilution on the rate and extent of oxidations in fermenting tea leaf suspensions // J. Biochem. 1940. N34. P. 500. 
48. Srerangachar H. Studies on the fermentation of Ceylon tea // J. Biochem. 1943. N37. P. 633.

49. Пруидзе Г.Н. Окислительно-восстановительные ферменты чайного растения и их роль в биотехнологии. Тбилиси, 1987. 186 с.

50. Мелкадзе Р.Г., Гулуа К.П. Внедрение технологии чаеподобных продуктов из нетрадиционного сырья. М., 1988. $24 \mathrm{c}$.

51. А.с. 1184513 (СССР). Способ получения заменителя чая из ежевичного листа / Р.Г. Мелкадзе, В.С. Фоменко, Л.Ш. Кутателадзе. 1983. Б.И. №38.

52. Патент 1828573 (СССР). Способ производства заменителя чая / Р.Г. Мелкадзе, В.С. Фоменко.1992.

53. Патент Грузии U 887. Способ производства заменителя чая / Р.Г. Мелкадзе. 2000.

Поступило в редакиџию 5 декабря 2013 г.

Melkadze R.G. LEAVES CAUCASIAN BLACKBERRY (RUBUS CAUCASICUS L.) - PROMISING RAW MATERIAL FOR THE PRODUCTION OF HERBAL TEA

Institute of Mechanics of machines, Mindeli st., 10, Tbilisi, 0186 (Georgia), e-mail: revmelk@ rambler.ru)

Studied some physical and chemical characteristics and 6-sheet blackberry shoot Caucasian (Rubus caucasicus L.). It was found that the minima of the moisture content, the extract substances and phenolic compounds to the same period of the beginning and end of the growing season of plants.

The composition of phenolic compounds represented by catechins, flavonols and leuco anthocyanidins. Highs accumulation of phenolic compounds during the growing season are found in the middle of the season (July-August).

The amount of free amino acids blackberry leaf vegetation monthly averages $26,68 \mathrm{mg} / \mathrm{g}$. 11 of the identified individual amino acids are essential 5 (GIS, Arg, Met, Leigh, Val).

The complex oxidative enzymes blackberry leaf established the presence of the active form of O-diphenol oxidase.

The tea product derived from blackberry leaf, has good organoleptic properties and a saturated extractive complex.

Keywords: Herbal teas, blackberry Caucasian, physical and chemical composition, phenolic substances, amino acids, oxidative enzymes, blackberry tea, technological scheme

\section{References}

1. Melkadze R., Chikovani N., Kachniashvili E. J. Applied Biochemistry and Microbiology, 2008, vol. 44, no. 6, pp. 647-651.

2. Melkadze R.G. Georgian Academy of Sciences, Tbilisi, 2000, no. 5, pp. 39-50.

3. Vorontsov V.E. Biokhimiia chaia. [Biochemistry of tea]. Moscow, 1946, 291 p. (in Russ.).

4. Popov V.R. Biokhimiia i progressivnaia tekhnologiia chainogo proizvodstva. [Biochemistry and advanced technology of tea production]. Moscow, 1966, pp. 110-115. (in Russ.).

5. Durmishidze S.V. Dubil'nye veshchestva $i$ antotsiany vinogradnoi lozy $i$ vina. [Tannins and anthocyanins of the vine and wine]. Moscow, 1955, 324 p. (in Russ.).

6. Durmishidze S.V., Nutsubidze N. Trudy NII vinograda $i$ vinodeliia AN GruzSSR. [Proceedings of the Research Institute of Vine and Wine Sciences of the Georgian SSR.]. 1954, vol. VIII, pp. 360. (in Russ.).

7. Soboleva G.A. Biokhimiia chainogo proizvodstva. [Biochemistry tea production]. Moscow, 1958, issue 7, pp. 76. (in Russ.).

8. Shipalov M.S., Bokuchava M.A., Soboleva G.A. Trudy instituta fiziologii rastenii AN SSSR. [Proceedings of the Institute of Plant Physiology of the USSR Academy of Sciences]. Moscow, 1962, no. 4, pp. 95. (in Russ.).

9. Filippovich Iu.B., Egorov T.A., Sevastianova G.A. Praktikum po obshchei biokhimii. [Workshop on general biochemistry]. Moscow, 1975, 318 p. (in Russ.).

10. Bokuchava M.A. Dubil'nye veshchestva i okislitel'nye fermenty gruzinskogo chaia: Avtoref. dis. ... doktora khim. nauk. [Tannins and oxidative enzymes Georgian tea: dissrtatsii Abstract of Doctor of Chemistry]. Moscow, 1950, 35 p. (in Russ.). 
11. Bokuchava M.A. Biokhimiia chainogo proizvodstva. [Biochemistry tea production]. Moscow, 1950, issue 6, pp. 20-30. (in Russ.).

12. Bokuchava M.A., Volkova A.G. Referaty rabot uchrezhdenii otdeleniia biologicheskikh nauk AN SSSR za 1945 g. [Reports of the institutions Division of Biological Sciences of the USSR for 1945]. Moscow, 1946. (in Russ.).

13. Bokuchava M.A., Novozhilov N.P. Biokhimiia chainogo proizvodstva. [Biochemistry tea production]. Moscow, 1946, issue 5, pp. 190. (in Russ.).

14. Bokuchava M.A., Popov V.R. Doklady AN SSSR, 1954, no. 99, pp. 145. (in Russ.).

15. Bokuchava M.A.,Popov V.R., Shubert T.A. Doklady AN SSSR, 1951, no. 76, pp. 439. (in Russ.).

16. Dzhemukhadze K.M. Biokhimiia chainogo proizvodstva. [Biochemistry tea production]. Moscow, 1940, issue 4, pp. 35-52. (in Russ.).

17. Dzhemukhadze K.M. Biokhimiia chainogo proizvodstva. [Biochemistry tea production]. Moscow, 1950, issue 6, pp. 39-52. (in Russ.).

18. Kursanov A.L. Biokhimiia chainogo proizvodstva. [Biochemistry tea production]. Moscow, 1935, issue 1, pp. 110127. (in Russ.).

19. Kursanov A.L. Biokhimiia, 1941, no. 6, pp. 312. (in Russ.).

20. Kursanov A.L. Biokhimiia, 1943, no. 8, pp. 188. (in Russ.).

21. Kursanov A.L. Izvestiia AN SSSR. Ser Biol., 1951, no. 2, pp. 44. (in Russ.).

22. Kursanov A.L. 7-e Bakhovskoe chtenie. AN SSSR. [7th Bach reading. USSR Academy of Sciences]. Moscow, 1952. (in Russ.).

23. Kursanov A.L., Kriukova N.I. Biokhimiia chainogo proizvodstva. [Biochemistry tea production]. Moscow, 1950, issue 6, pp. 7-19. (in Russ.).

24. Bradfield A. Chem. and Ind., 1946, vol. 326, pp. 242.

25. Lame J. J. of res. Inst. of Ceylon, 1937, pp. 36.

26. Roberts E., Wood D.A. Biochem. J., 1951, no. 49, pp. 414.

27. Tsujimura M. Chem.abstr., 1947, no. 41, pp. 5924.

28. Tsujimura M., Takasu E. Ibid., 1955, pp. 407.

29. Melkadze R. Pivo i napitki, 2004, no. 2, pp. 102-105. (in Russ.).

30. Bokhinskii R. Sovremennye vozzreniia v biokhimii. [Modern views in biochemistry]. Moscow, 1987, 544 p. (in Russ.).

31. Gudvin T., Merser E. Vvedenie biokhimii rastenii. [Introduction of Plant Biochemistry]. In 2 vol. Moscow, 1986, vol. 2, 312 p. (in Russ.).

32. Kretovich V.L. Osnovy biokhimii rastenii. [Основы биохимии растений]. Moscow, 1971, 464 p. (in Russ.).

33. Bokuchava M.A., Popov V.R., Sidorov V.S. Doklady AN SSSR, 1954, no. 95, pp. 609. (in Russ.).

34. Oshima J., Nakabayashi T., Sakamoto J. Ibid., 1954, pp. 264.

35. Petrov K.P. Praktikum po biokhimii rastitel'nogo syr'ia. [Practical work on biochemistry of plant raw materials]. Moscow, 1965, 330 p. (in Russ.).

36. Glazunov I.V. Biokhimiia chainogo proizvodstva. [Biochemistry tea production]. Moscow, 1935, issue 1, pp. $76-87$. (in Russ.).

37. Kursanov A.L. Biokhimiia chainogo proizvodstva. [Biochemistry tea production]. Moscow, 1935, issue 1, pp. 88-94. (in Russ.).

38. Manskaia S.M. Biokhimiia chainogo proizvodstva. [Biochemistry tea production]. Moscow, 1935, issue 1, pp. 96-109. (in Russ.).

39. Oparin A.I. Biokhimiia chainogo proizvodstva. [Biochemistry tea production]. Moscow, 1935, issue 1, pp. 6-19. (in Russ.).

40. Oparin A.I., Shubert T.A. Biokhimiia chainogo proizvodstva. [Biochemistry tea production]. Moscow, 1935 , issue 1. (in Russ.).

41. Kharebava G.I. Biokhimiia chainogo proizvodstva. [Biochemistry tea production]. Moscow, 1946, issue 6, pp. 85. (in Russ.).

42. Kharebava G.I. Biulleten' Vsesoiuznogo nauchno-issledovatel'skogo instituta chaia i subtropicheskikh kul'tur. [Bulletin of the National Research Institute of Tea and Subtropical Crops]. 1949, no. 4, pp. 49. (in Russ.).

43. Harrison C., Roberts E. J. Biochem., 1939, no. 33, pp. 1408-1420.

44. Roberts E. J. Biochem., 1939, no. 33, pp. 842.

45. Roberts E. Ibid., 1941, no. 35, pp. 10.

46. Roberts E. Enzimol., 1942, no. 2, pp. 113.

47. Roberts E. J. Biochem., 1940, no. 34, pp. 500-516.

48. Srerangachar H. J. Biochem., 1943, no. 37, pp. 633.

49. Pruidze G.N. Okislitel'no-vosstanovitel'nye fermenty chainogo rasteniia i ikh rol'v biotekhnologii. [Redox enzymes tea plants and their role in biotechnology]. Tbilisi, 1987, 186 p. (in Russ.).

50. Melkadze R.G., Gulua K.P. Vnedrenie tekhnologii chaepodobnykh produktov iz netraditsionnogo syr'ia. [The introduction of technology chaepodobnyh products from non-traditional raw materials]. Moscow, 1988, 24 p. (in Russ.).

51. Patent 1184513 (USSR). 1983. (in Russ.).

52. Patent 1828573 (USSR). 1992. (in Russ.).

53. Patent GEU2002887 (GE). 2002. 